\title{
Mulched cover crops as an alternative to conventional weed management systems in vineyards
}

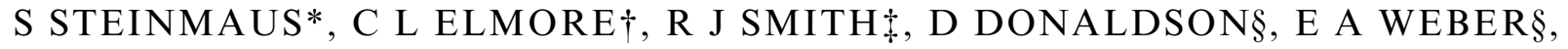 \\ $\mathrm{J} A \mathrm{RONCORONI \dagger} \& \mathrm{P} \mathrm{R}$ M MILLER** \\ *Department of Biological Sciences, California Polytechnic State University, San Luis Obispo, CA, USA, †Department of Plant Sciences, \\ University of California, Davis, CA, USA, †University of California Cooperative Extension, Sonoma County, Santa Rosa, CA, USA, \\ $\S$ University of California Cooperative Extension, Napa County, Napa, CA, USA and **Department of Rural Engineering, Federal University of \\ Santa Catarina, Florianópolis, SC, Brazil
}

\section{Summary}

Conventional methods of weed management in vineyards rely primarily on herbicides and tillage. The desire to adopt alternatives to these methods is driven by environmental and economic reasons. Weed suppression and grape yield under mulched cover crop systems at two rainfed northern California vineyards were similar to, and at times exceeded, those under conventional tillage or herbicide management. Cover crop productivity was positively correlated with weed suppression and mulch decomposition rates and seemed to be determined primarily by location and then by cover crop type. The mulch from mowed cover crops averaged $603( \pm 94) \mathrm{gm}^{-2}$ at the two sites. Weed suppression was linked to light interception by the mulch cover for most weed species. Subterranean clover planted directly in the vine row significantly reduced weed cover where it established. The increased dominance of the perennial Convolvulus arvensis and reduction of certain annual species was indicative of species compositional changes in all treatments. Profits under the cover cropping systems exceeded those under conventional tillage and herbicide systems by $€ 794 \mathrm{ha}^{-1}$ averaged over the duration of the experiment at both locations.

Keywords: grapes, light interception, profit, species richness, subclover, Trifolium subterranean, vegetation management, vines, yield.

\section{Introduction}

Weeds in vineyards can cause significant reductions in vine growth and grape yields (Hembree \& Lanini, 2006). Conventional control methods used in California include a complete no tillage system that relies on herbicide applications in the vine rows and the area between them (middles), or a combination of herbicide strip application in the vine row and mowing or disking of the middles. Concern about significant weed growth by not using herbicides has limited the adoption of organic methods, such as cover cropping and mulching (Bond \& Grundy, 2001).
Cover crops have been utilised to reduce weed management costs, as well as to enhance soil characteristics (Hartwig \& Ammon, 2002; Fageria et al., 2005). In these situations, efficacy of mowed or desiccated mulch to manage weeds seems to depend most on soil coverage and its effect on light interception, rather than on the effects of altered moisture or temperature regimes, allelopathy or mechanical impedance (Teasdale, 1993; Teasdale \& Mohler, 1993; Liebman \& Davis, 2000). Teasdale et al. (1991) estimated that about half the bare ground must be covered for any reduction in weed density. Ground cover greater than $50 \%$ results in a roughly exponential increase in weed suppression. 
Unfortunately, depending on environmental conditions, mulches can break down rapidly, resulting in insufficient soil coverage and thus allowing weed establishment (Facelli \& Pickett, 1991; Teasdale \& Mohler, 1993). Cover crop mulches comprised of grass species have been found to provide similar coverage and light interception as those composed of legumes, but the legumes breakdown sooner (Teasdale \& Mohler, 1993).

Species compositional changes have been observed for different weed management systems (Wrucke \& Arnold, 1985; Teasdale et al., 1991). Species numbers can be significantly reduced in no-till herbicide systems, with annual grasses and perennial weed species predominating (Zaragoza et al., 1989). Some weed species show no unique association with management practices, growing equally well in all systems (Wrucke \& Arnold, 1985; Zaragoza et al., 1989). Changes in species composition where plant residue covers the soil depends on the species involved and patchiness of the plant residue (Facelli \& Pickett, 1991). Farm managers must anticipate whether a single management regime will result in a weed flora that is difficult to control by any available method. Consequently, there is a need to further document the response of weed flora to various types of management including cover crop mulches (Dastgheib \& Frampton, 2000).

Concerns over how cover crops and their mulches might adversely affect vines have slowed down the adoption of these systems. Concerns include increased pathogenicity, vertebrate and invertebrate pests, competition with the vines and higher nutrient availability. Regardless of potential benefits and risks, grape yield and economic return associated with a system usually concerns vineyard managers most.

We compared the effects of mulch from mowed cover crop systems with those of conventional weed management methods for weed suppression, compositional change, grape yield and economic return at two commercial vineyards in Sonoma County in northern California. We tested the results of this study against a null hypothesis 'o' no significant difference for the assessed effects between the mulched and conventional systems.

\section{Materials and methods}

\section{Experimental design}

Studies were conducted at two commercial vineyards located in Sonoma County, a renowned grape growing region in northern California. The first site (Carneros) was located in the Los Carneros American Viticultural Area (AVA) in south-eastern Sonoma County with a Haire series clay loam soil type (34\% clay, $34 \%$ sand,
$2 \%$ organic matter and the remainder silt of the size class, 0.002-0.05 mm). The second site (Dry Creek) was located in the Dry Creek AVA in northern Sonoma County with a Manzanita series gravelly silt loam ( $21 \%$ clay, $30 \%$ sand and $0.7 \%$ organic matter) soil type. The experiment was a randomised complete block design replicated four times. Main plot size was four vine rows, $100 \mathrm{~m}$ long by $1.5 \mathrm{~m}$ wide directly beneath each vine row. The five main treatments were three mulched cover crops, mulched resident vegetation and a conventional method. The conventional method was a herbicide application at Carneros and in-row cultivation at Dry Creek. Reseeding subterranean clover (Trifolium subterranean L. mixture of inoculated varieties: Junee, Trikala and Koala; referred to as subclover) was sowed at $75-85 \mathrm{~kg} \mathrm{ha}^{-1}$ as a subplot in the vine row half the length of the cover crop main plots at both locations.

The cover crop main plots at both locations consisted of oats (Avena sativa L. var. Ogle; planted at 70 and $101 \mathrm{~kg} \mathrm{ha}^{-1}$ at Carneros and Dry Creek, respectively), Vicia benghalensis L.; planted at 59 and $94 \mathrm{~kg} \mathrm{ha}^{-1}$ at Carneros and Dry Creek, respectively), and a 50:50 oatvetch combination (planted at 102 and $112 \mathrm{~kg} \mathrm{ha}^{-1}$ at Carneros and Dry Creek, respectively). These treatments were established into cultivated soil in the $2.5 \mathrm{~m}$ region (middles) between the vine rows each autumn, beginning in 1991 with a precision drill planter. As a control treatment, vegetation from the resident seedbank was allowed to grow in the middles. In April of each year, these four treatments were mowed with a modified flail mower, so that the mowed vegetation was deposited into the vine row by a rear-mounted conveyor (Trimax Mulchmasta with Sidewinder, Trimax Mowing Systems, Tauranga, New Zealand; http:/www.trimaxmowers.com). The result was a dense, concentrated mulch layer in the strip directly underneath the vines. After mowing, the middles of all main plots were disked.

In October of 1991 at Carneros, the conventional management treatment (herbicide) consisted of an application of oryzalin (Surflan AS, $479 \mathrm{~g}$ a.i. L ${ }^{-1}$, AS, DowAgroSciences, Indianapolis, IN, USA) at $4.4 \mathrm{~kg}$ a.i. $\mathrm{ha}^{-1}$, oxyfluorfen (Goal 2XL, $239 \mathrm{~g}$ a.i. $\mathrm{L}^{-1}$, L, Rohm and Haas, Philadelphia, PA, USA) at $1.6 \mathrm{~kg}$ a.i. ha ${ }^{-1}$ and glyphosate (Roundup, $356 \mathrm{~g}$ a.i. $\mathrm{L}^{-1}$, E, Monsanto, St. Louis, MO, USA) at $0.8 \mathrm{~kg}$ a.i. $\mathrm{ha}^{-1}$. The same mixture with simazine (Princep 4 L, 479 g a.i. L ${ }^{-1}$, L, Syngenta, Greensboro, NC, USA) at $2.2 \mathrm{~kg} \mathrm{ha}^{-1}$ substituted for oxyfluorfen was applied in the winters of 1992, 1993 and 1994. At Dry Creek, a vine row cultivator (Kimco Mfg, Fresno, CA, USA; http://www.kimcomfg.com) was utilised as the conventional treatment (cultivation) in April of each year. 


\section{Data collection}

Precipitation records at each location for the period spanning the duration of the project were downloaded from the University of California Integrated Pest Management Program web site (http://www.ipm.ucdavis.edu/). Weed and mulch cover in the vine rows were assessed in January, March, June and August in 1992, 1993 and 1994. The point-intercept method was utilised to assess percentage weed cover at both locations. Four $30 \mathrm{~m}$ transects were laid directly under the vines in each plot. A $1 \mathrm{~cm}$ diameter rod was lowered vertically to the ground at $30 \mathrm{~cm}$ intervals along the transect. Any weed species in addition to mulch or bare ground intercepted by the rod were recorded and used to estimate percent cover for each. Just prior to mulching in 1993 and 1994, four $0.25 \mathrm{~m}^{2}$ quadrats were randomly placed in the middles of each cover crop and resident plot, clipped and dried to estimate mulch biomass that would be placed in the vine row by the flail mower. At the same time, paired measurements of photosynthetic photon flux (PPF, $\mu \mathrm{M} \mathrm{m}^{-2} \mathrm{~s}^{-1}$ ) were taken in the vine row at soil level and just above the mulch with an $80 \mathrm{~cm}$ Sunfleck Ceptometer (Decagon Devices, Washington, USA; http://www.decagon.com).

Each autumn beginning in 1991, six vines per subplot were picked by hand and weighed immediately at each location to assess berry yield. A subsample of 200 berries within each subplot were randomly selected and assessed for soluble solids ( ${ }^{\circ}$ Brix) using a handheld refractometer (N1, Atago, Itabashi-ku, Tokyo, Japan; http:// www.atago.net). Titratable acidity $\left(\mathrm{g} \mathrm{L}^{-1}\right)$ and $\mathrm{pH}$ were also measured on the berry samples with a $\mathrm{pH}$ meter (Radiometer PHM 84, Radiometer America, Cleveland, OH, USA; http://www.radiometer-analytical.com). An economic assessment of all costs associated with production within each treatment was done each year at each location. Costs within each treatment included labour and supplies such as seed, fertiliser, inoculum or herbicides, as well as the maintenance and depreciation cost of equipment associated with each treatment, such as planters, mower, cultivators and tractors (Cross \& Perry, 1995). Revenues included grape berry yield with an assumed purchase price of $€ 1.04 \mathrm{~kg}^{-1}$.

\section{Data analyses}

The weed cover data were natural log transformed after adding a constant to meet assumptions of analysis of variance (Berry, 1987). The analyses were performed using the GLM procedure with the REPEATED option to assess the repeated measurement effects of time (year and assessment date) and any interaction involving time in SAS [SAS for Windows Version 9.1 (2002-2003)].
Multiple comparisons involving time effects were performed by defining the desired contrasts in the M-matrix and utilising the MANOVA statement. Multiple comparisons of treatment effects within or summed over a time effect were accomplished by Tukey's HSD-test $(\propto=0.05)$. All treatment effects and significant interactions were back transformed for presentation.

Weed flora changes were assessed by estimating species richness from species observations in the transects by the Jackknife method (Krebs, 1999). Canonical correspondence analysis (CCA) was used to arrange all weed species along the measured environmental gradients in CANOCO (Leps \& Smilauer, 2003) to elucidate weed compositional changes and associations as they might be affected by environmental variables. The quantitative environmental variables were species richness, year, mulch cover, total precipitation for the 3 months prior to each assessment date and a cumulative precipitation beginning in November of each year through to October of the subsequent year. The nominal environmental variables were the main treatments at both locations and subtreatment at Dry Creek as subclover did not establish at Carneros.

\section{Results}

\section{Cover crop mulch}

The 1992 growing season was typical for Sonoma County, with a total cumulative rainfall of about $48 \mathrm{~cm}$. Precipitation was unusually high in 1993 averaging $76 \mathrm{~cm}$ but drier in 1994 averaging $33 \mathrm{~cm}$. Most precipitation occurred in the winter months with only $5 \mathrm{~cm}$ of rainfall for June to September for 1992, 1993 and 1994.

The light (assumed 100\%), mulch (assumed $0 \%$ ) and weed cover data from 1992 before any mulch was applied were used as initial levels in the 1993 and 1994 regressions (Fig. 1). The ability of mulch cover to suppress weed cover was best characterised by a linear function in 1993 and as an exponential decay function in 1994 at Carneros and Dry Creek (Fig. 1A and B). A regression using 1994 data from Dry Creek that excluded all subplots originally sown with subclover resulted in a linear function similar to the one fitted to the 1993 data (not presented). This reflected residual weed suppression, even though subclover reestablishment was poor in 1994 for unknown reasons. Light (PPF) attenuation appeared to be a linear function of percent mulch cover at both locations in all years (Fig. 1C and D).

Mulch cover in 1993 and 1994 that persisted from the previous season before application was significantly higher $(P<0.01)$ at Dry Creek than Carneros, 81 


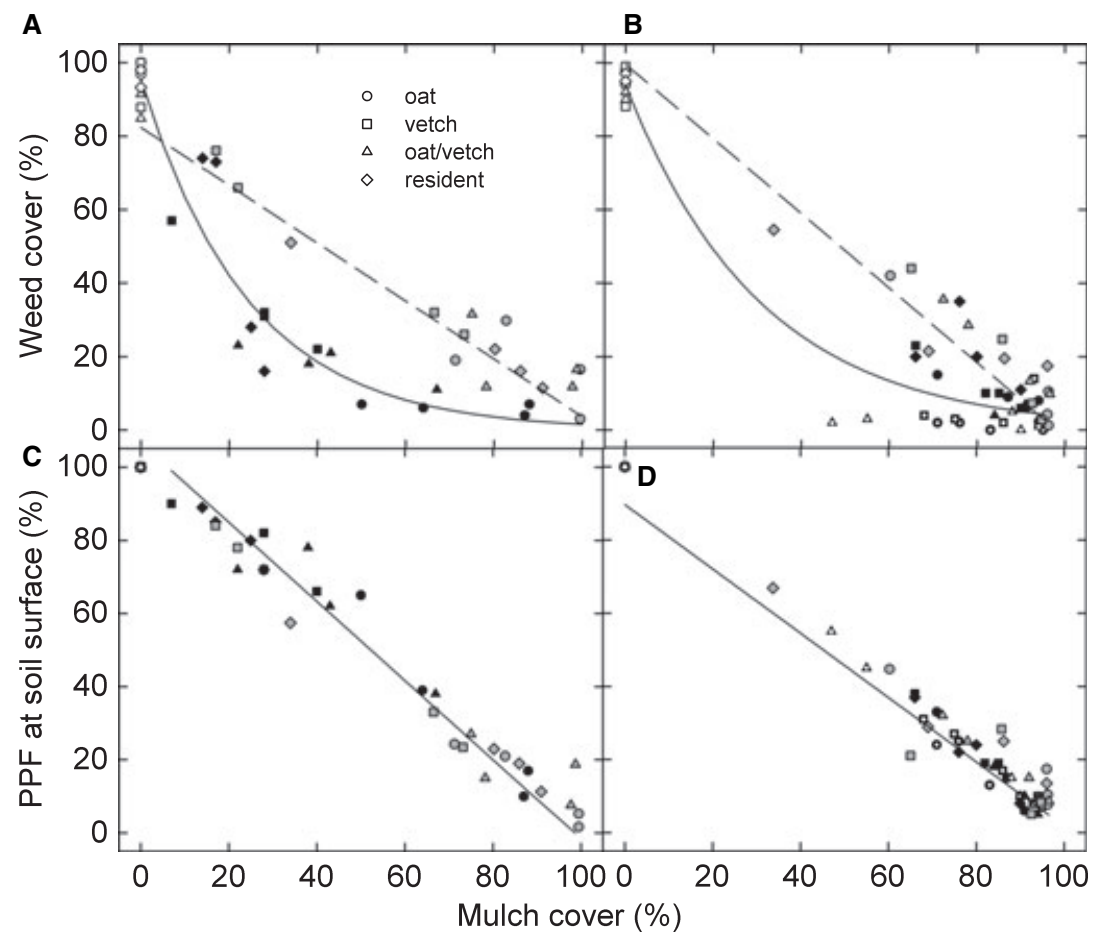

Fig. 1 Weed cover (WC) and percent of photosynthetic flux (PPF) at mulch surface taken at soil level as functions of mulch cover (MC). (A) Weed suppression at Carneros in 1993 (dashed line and grey symbols): $\mathrm{WC}=82.3(20.1)-0.79(0.22) \mathrm{MC}, r^{2}=0.83$; in 1994 (solid line black symbols): $\mathrm{WC}=95.4(7.0) \exp -0.04(0.01) \mathrm{MC}, r^{2}=0.81$. (B) Weed suppression at Dry Creek in 1993 (dashed line, black symbols): $\mathrm{WC}=99.5(25.4)-1.01(0.26) \mathrm{MC}, r^{2}=0.79$; in 1994 (solid line, black symbols): $\mathrm{WC}=94.0(1.8) \exp -0.032(0.002) \mathrm{MC}, r^{2}=0.87 .(\mathrm{C})$ Light attenuation at Carneros all years: PPF $=106.6(31.7)-1.08(0.39) \mathrm{MC}, r^{2}=0.96$. (D) Light attenuation at Dry Creek all years: $\mathrm{PPF}=89.7(21.3)-0.88(0.23) \mathrm{MC}, r^{2}=0.75$. Data from 1992 (hollow symbols) were used as initial background levels in all regressions. Symbols with crosses were subplots sowed with subclover at Dry Creek. SE in parentheses.

Table 1 Percent cover remaining from the previous season (persisting cover) in the vine row just prior to mulching in 1992,1993 and 1994. The mulched biomass $\left(\mathrm{g} \mathrm{m}^{-2}\right.$ ) from vineyard middles applied to the vine rows (Biomass applied), and resulting percent cover in the vine row following mulching (Resulting cover) at the Carneros and Dry Creek sites in the mulched main treatments. SE of the mean in parentheses

\begin{tabular}{|c|c|c|c|c|c|c|c|}
\hline & & \multicolumn{2}{|c|}{ Persisting cover (\%) } & \multicolumn{2}{|c|}{ Biomass applied $\left(\mathrm{g} \mathrm{m}^{-2}\right)$} & \multicolumn{2}{|c|}{ Resulting cover (\%) } \\
\hline & & Carneros & Dry Creek & Carneros & Dry Creek & Carneros & Dry Creek \\
\hline \multirow[t]{4}{*}{1992} & Oat & 0.00 & 0.00 & - & - & $92.0(3.0)$ & $87.4(3.0)$ \\
\hline & Vetch & 0.00 & 0.00 & - & - & $68.3(9.3)$ & $95.9(1.9)$ \\
\hline & Oat/vetch & 0.00 & 0.00 & - & - & $91.8(3.4)$ & $94.3(3.4)$ \\
\hline & Resident & 0.00 & 0.00 & - & - & $52.0(14.8)$ & $73.4(6.5)$ \\
\hline \multirow[t]{4}{*}{1993} & Oat & $71.6(17.9)$ & $71.0(7.5)$ & 1186(34) & $263(26)$ & $93.6(3.2)$ & $84.6(10.4)$ \\
\hline & Vetch & $68.4(6.8)$ & $92.8(3.6)$ & $508(18)$ & 206(15) & $76.3(7.4)$ & $86.1(7.6)$ \\
\hline & Oat/vetch & $65.8(15.7)$ & $90.0(4.2)$ & 1013(33) & $469(26)$ & $86.6(2.4)$ & $96.5(1.6)$ \\
\hline & Resident & $49.9(26.4)$ & $65.8(10.2)$ & $549(27)$ & $66(12)$ & $77.9(6.0)$ & $85.2(4.8)$ \\
\hline \multirow[t]{4}{*}{1994} & Oat & $72.3(9.2)$ & $83.5(5.1)$ & 1099(41) & $360(18)$ & $94.7(1.2)$ & $86.5(6.4)$ \\
\hline & Vetch & $25.8(7.0)$ & $83.9(4.8)$ & $501(21)$ & $473(36)$ & $84.8(1.2)$ & $91.3(5.4)$ \\
\hline & Oat/vetch & $42.5(9.3)$ & $84.8(6.6)$ & 1367(56) & $514(49)$ & $90.1(2.0)$ & $87.6(5.4)$ \\
\hline & Resident & $21.0(3.3)$ & $77.9(4.9)$ & $779(28)$ & $296(12)$ & $86.2(1.8)$ & $91.3(6.9)$ \\
\hline
\end{tabular}

$( \pm 3.2) \%$ and $52( \pm 7.3) \%$ cover, respectively (Table 1$)$. Mulch biomass applied to the vine row at Carneros in 1993 and 1994 was in excess of $1000 \mathrm{~g} \mathrm{~m}^{-2}$ in the oat and oat-vetch cover crop treatments and exceeded $500 \mathrm{~g} \mathrm{~m}^{-2}$ in the vetch and resident treatments, while biomass ranged from $66 \mathrm{~g} \mathrm{~m}^{-2}$ to $514 \mathrm{~g} \mathrm{~m}^{-2}$ at Dry Creek (Table 1). Resulting mulch cover following application to the vine rows every year was similar at both locations, averaging $88 \%$ cover. As with all annual vegetation, subterranean clover growth at Dry Creek 
was greatest after the highest precipitation periods in 1993, attaining $42.0( \pm 7.2) \%$ cover but only 11.1 $( \pm 2.1) \%$ in 1994. Subclover did not establish at Carneros, perhaps because of the heavy soil type and high mulching rates from the main treatments.

\section{Weed suppression}

Total weed cover was significantly higher $(P<0.01)$ at Carneros $(28.5 \%)$ than at Dry Creek $(18.2 \%)$ across all treatments and assessment dates. However, treatments with the highest weed cover were different within each location (Table 2). Weed cover was significantly higher $(P<0.05)$ in the vetch treatment at Carneros than the other treatments and in the resident and cultivated at Dry Creek. Overall, weed cover mirrored precipitation patterns, being highest in 1993 (Table 2). However, that was due primarily to the significantly higher $(P<0.01)$ weed cover only at Dry Creek in that year.

Before mulching each year at Carneros, the vetch treatment consistently had the highest weed cover, where Brassica nigra (L.) W.D.J. Koch (12.6 \pm 3.4\%), Malva parviflora L. $(3.2 \pm 1.2 \%)$, and Sonchus oleraceus L. $(2.5 \pm 1.7 \%)$ comprised most of the total weed cover (Table 3). By the end of the growing season in August, there were no significant differences among treatments for total weed cover averaged across all years (Table 3). Convolvulus arvensis became the dominant summer weed species especially in the herbicide plots increasing from $7.9( \pm 2.1) \%$ cover in August 1992 to $18.8( \pm 3.1) \%$ by August 1994.

At Dry Creek, the cultivated treatment had a significantly $(P<0.05)$ higher weed cover than the other main treatments before mulching in 1993 and 1994 (Table 3). Stellaria media L. $(11.0 \pm 3.2 \%)$ was the

Table 2 Average weed cover (\%) at Carneros and Dry Creek over all assessment dates for the two way interactive effects of location by main treatment and location by year. Means within each location columns within the 'Treatment' or 'Year' section sharing a common letter are not significantly different. The treatment and year main effects are presented under 'Mean' column

\begin{tabular}{lcllc}
\hline \multirow{4}{*}{ Treatment } & \multicolumn{3}{l}{ Location } \\
\cline { 3 - 5 } & & Carneros & Dry Creek & Mean \\
\cline { 3 - 5 } & Oat & $21.8 \mathrm{c}$ & $15.6 \mathrm{~b}$ & 18.4 \\
& Vetch & $44.0 \mathrm{a}$ & $17.1 \mathrm{~b}$ & 27.4 \\
& Oat/vetch & $24.1 \mathrm{bc}$ & $17.3 \mathrm{~b}$ & 20.4 \\
Year & Resident & $28.3 \mathrm{~b}$ & $24.1 \mathrm{a}$ & 26.1 \\
& Conv. $^{*}$ & $15.5 \mathrm{c}$ & $23.3 \mathrm{a}$ & - \\
& 1992 & $31.1 \mathrm{a}$ & $11.9 \mathrm{~b}$ & 19.3 \\
& 1993 & $28.2 \mathrm{a}$ & $38.5 \mathrm{a}$ & 32.9 \\
& 1994 & $26.3 \mathrm{a}$ & $13.2 \mathrm{~b}$ & 18.6 \\
\hline
\end{tabular}

*Conventional treatments, herbicide at Carneros and cultivated at Dry Creek. dominant winter species at Dry Creek in 1992 but was displaced by the Erodium spp.(17.1 $\pm 4.5 \%)$ as dominant by 1994. Epilobium brachycarpum C. Presl $(4.6 \pm 2.1 \%)$ was dominant at the end of the season, when there were no significant differences for total weed cover among the treatments any year. The most significant weed suppressive effect at Dry Creek occurred in the subplots where weed cover was significantly $(P<0.001)$ reduced wherever subclover was originally sown (Table 3). This was true regardless of the main cover crop treatment in all years except 1992 before mulching, just as the subclover became established (data not presented).

\section{Weed flora associations}

The species composition at both locations was typical of California north coast vineyards. At Carneros, mulch cover $\left(r_{\text {mulch-CCA1 }}=0.77\right)$ and year $\left(r_{\text {year-CCA1 }}=0.88\right)$ had the longest arrows in the ordination and thus were strongly related to community structure prior to mulching each year (Fig. 2). Species richness arrows were not strongly related to community structure but pointed away from the herbicide centroid at Carneros in March and toward the cultivation centroid at Dry Creek in August. This was indicative of the significant $(P<0.001) \quad 14.5( \pm 2.1) \%$ decrease and significant $(P<0.001) 17.5( \pm 3.5) \%$ increase in species richness in the herbicide and cultivated treatments, respectively, over the course of the experiment. The dominant winter species at Carneros and Dry Creek, B. nigra (no.5) and Erodium moschatum (L.) L'Hér. ex Aiton (no.16), respectively, had scores close to the axes origins, indicating their ubiquity in all plots in all years (Fig. 2A and B). Based on the ordering of the perpendicular projection of species scores onto the environmental arrows (or their extensions), the increased abundance of $C$. arvensis (species no.12) over the course of the experiment can be seen by its top ranking along the year arrow in March at Carneros and Dry Creek (Fig. 2A and B). Other species can be interpreted similarly according to their rankings along the environmental arrows or treatment centroids. Short distances between species scores is indicative of their co-occurrence in the transects. By the end of the growing season in August, most species scores were farthest from the herbicide centroid relative to the other treatments, which indicated their low abundances in that treatment.

The CCA revealed that subclover presence did not affect species composition at Dry Creek based on their relatively small arrows (Fig. 2B and D). However, the distance of the subclover subplot centroid (subtrt) from the CCA axes origin indicated that species composition in subplots originally sowed with subclover was affected. 
Table 3 Average weed cover (\%) for main treatment and subtreatment effects in March (before mulching) and August (end of season) from 1992 to 1994 at Carneros and Dry Creek. Average weed cover in subtreatments from Dry Creek subplots sowed (+SC) and not sowed (-SC) with subclover. At each location within each column, percent weed cover sharing a common letter are not significantly different

\begin{tabular}{|c|c|c|c|c|c|c|c|c|c|}
\hline & & \multicolumn{4}{|c|}{ Before mulching } & \multicolumn{4}{|c|}{ End of season } \\
\hline & & \multicolumn{8}{|c|}{ Total Weed Cover } \\
\hline & & 1992 & 1993 & 1994 & Mean & 1992 & 1993 & 1994 & Mean \\
\hline \multirow[t]{7}{*}{ Carneros } & Treatment & & & & & & & & \\
\hline & Oat & $80.1 a$ & $78.5 b$ & $5.9 c$ & 54.8 & $41.1 \mathrm{a}$ & $18.0 \mathrm{a}$ & $19.4 b$ & 26.2 \\
\hline & Vetch & $83.2 \mathrm{a}$ & $113.9 a$ & $33.4 a$ & 76.8 & $41.7 a$ & $31.3 a$ & $24.1 \mathrm{ab}$ & 32.4 \\
\hline & Oat/vetch & $63.6 a$ & $62.5 b c$ & $17.3 b$ & 47.8 & $30.6 a$ & $16.4 a$ & $22.2 \mathrm{ab}$ & 23.1 \\
\hline & Resident & $50.1 \mathrm{a}$ & $24.4 d$ & $39.9 a$ & 38.1 & $50.4 a$ & $21.9 a$ & $16.9 \mathrm{~b}$ & 29.7 \\
\hline & $\begin{array}{l}\text { Herbicide } \\
\text { Mean }\end{array}$ & $84.9 a$ & $54.3 c$ & $17.3 b$ & 52.2 & $37.1 \mathrm{a}$ & $15.2 \mathrm{a}$ & $32.7 a$ & 28.3 \\
\hline & & 72.4 & 66.7 & 22.8 & & 40.2 & 20.6 & 23.1 & \\
\hline \multirow[t]{10}{*}{ Dry Creek } & Treatment & & & & & & & & \\
\hline & Oat & $38.4 a$ & $41.5 c$ & $9.1 \mathrm{bc}$ & 29.7 & 13.5 & 20.2 & 9.7 & 14.5 \\
\hline & Vetch & $31.4 a$ & $84.3 b$ & $10.8 \mathrm{bc}$ & 42.2 & 13.1 & 25.8 & 5.0 & 14.6 \\
\hline & Oat/vetch & $35.5 a$ & $78.8 \mathrm{~b}$ & $4.5 \mathrm{c}$ & 39.6 & 12.7 & 27.4 & 8.1 & 16.1 \\
\hline & Resident & $44.1 \mathrm{a}$ & $74.0 \mathrm{~b}$ & $19.8 \mathrm{~b}$ & 46.0 & 25.3 & 23.8 & 7.9 & 19.0 \\
\hline & $\begin{array}{l}\text { Cultivated } \\
\text { Mean }\end{array}$ & 48.3a & $123.9 a$ & $47.6 a$ & 73.3 & 37.9 & 22.4 & 10.5 & 23.6 \\
\hline & & 39.5 & 80.5 & 18.4 & & $20.5 a$ & $23.9 a$ & $8.2 b$ & \\
\hline & Subtreatment & & & & & & & & \\
\hline & $+\mathrm{SC}$ & $31.7 a$ & $31.4 b$ & $2.7 \mathrm{~b}$ & 21.9 & 3.3 & 4.1 & 2.1 & $3.2 b$ \\
\hline & $-\mathrm{SC}$ & $38.0 a$ & $77.0 \mathrm{a}$ & $8.6 a$ & 41.2 & 13.4 & 24.5 & 7.4 & $15.1 \mathrm{a}$ \\
\hline
\end{tabular}

Therefore, the presence of subclover cover was not required to see an effect on species composition, only its presence at the beginning of the experiment.

\section{Grape yield and profit}

There were no significant main or subtreatment differences in grape yield averaged across all years at either Carneros or Dry Creek (Fig. 3). However, berry yields at Carneros were significantly higher $(P<0.001)$ in 1993 and 1994, averaging 14.8 tonnes ha ${ }^{-1}$ compared with the 1991 and 1992 average of 7.1 tonnes $\mathrm{ha}^{-1}$, which reflects the young age of the vines (4 years in 1992). At Dry Creek, there was a significant year effect $(P<0.001)$ where berry yields were $28.9,21.9,14.3$ and 19.9 tonnes ha ${ }^{-1}$ in 1991, 1992, 1993 and 1994, respectively. There were no consistently significant grape quality differences in terms of ${ }^{\circ} \mathrm{Brix}, \mathrm{pH}$, or titratable acidity among the main or subtreatments within each year at either location (data not presented).

Net return (profit) of the cover cropping systems averaged 1029 and $560 €$ ha $^{-1}$ more at Carneros and Dry Creek, respectively, relative to the conventional treatments (Table 4). However, there was a net average loss of $735 € \mathrm{ha}^{-1}$ in the cover cropping systems in 1992. Most of those relative losses were associated with a difference in revenue, which was primarily associated with lower yields in the vetch and oat/vetch treatments at Carneros and the oat and resident treatments at Dry Creek that year.

\section{Discussion}

Teasdale and Mohler (1993) estimated that at least $600 \mathrm{~g} \mathrm{~m}^{-2}$ would be required to reduce light (PPF) levels to below those required for germination of most weed species. The mulch application rates at Carneros were well in excess of $600 \mathrm{~g} \mathrm{~m}^{-2}$, averaging $875 \mathrm{~g} \mathrm{~m}^{-2}$ perhaps because the cover crops were grown in the middles and concentrated into the vine row when mulched. Meanwhile, at Dry Creek, where mulching rates averaged $331 \mathrm{~g} \mathrm{~m}^{-2}$, only the oat/vetch treatment was close to the $600 \mathrm{~g} \mathrm{~m}^{-2}$ threshold. Mulching rates at both locations resulted in similar mulch coverage (88\%), yet weed cover averaged a significant $10 \%$ higher at Carneros than Dry Creek. Thus, the higher mulching rates at Carneros were required to offset the higher weed pressure. If mulch application rates were higher at Carneros, yet the mulch cover that persisted to subsequent years was nearly $30 \%$ lower at Carneros, then mulch breakdown rates must be higher at Carneros. At Dry Creek, mulch breakdown rates were low in all mulched treatments with an average $81 \%$ mulch cover persisting throughout each year following $89 \%$ mulch cover being applied the previous spring. Therefore, it appears that the factors which limited primary productivity at Dry Creek may also limit mulch breakdown rates.

Based on mulch and weed cover regressions (Fig. 1A and B), $35 \%$ and $42 \%$ mulch cover would be required to 


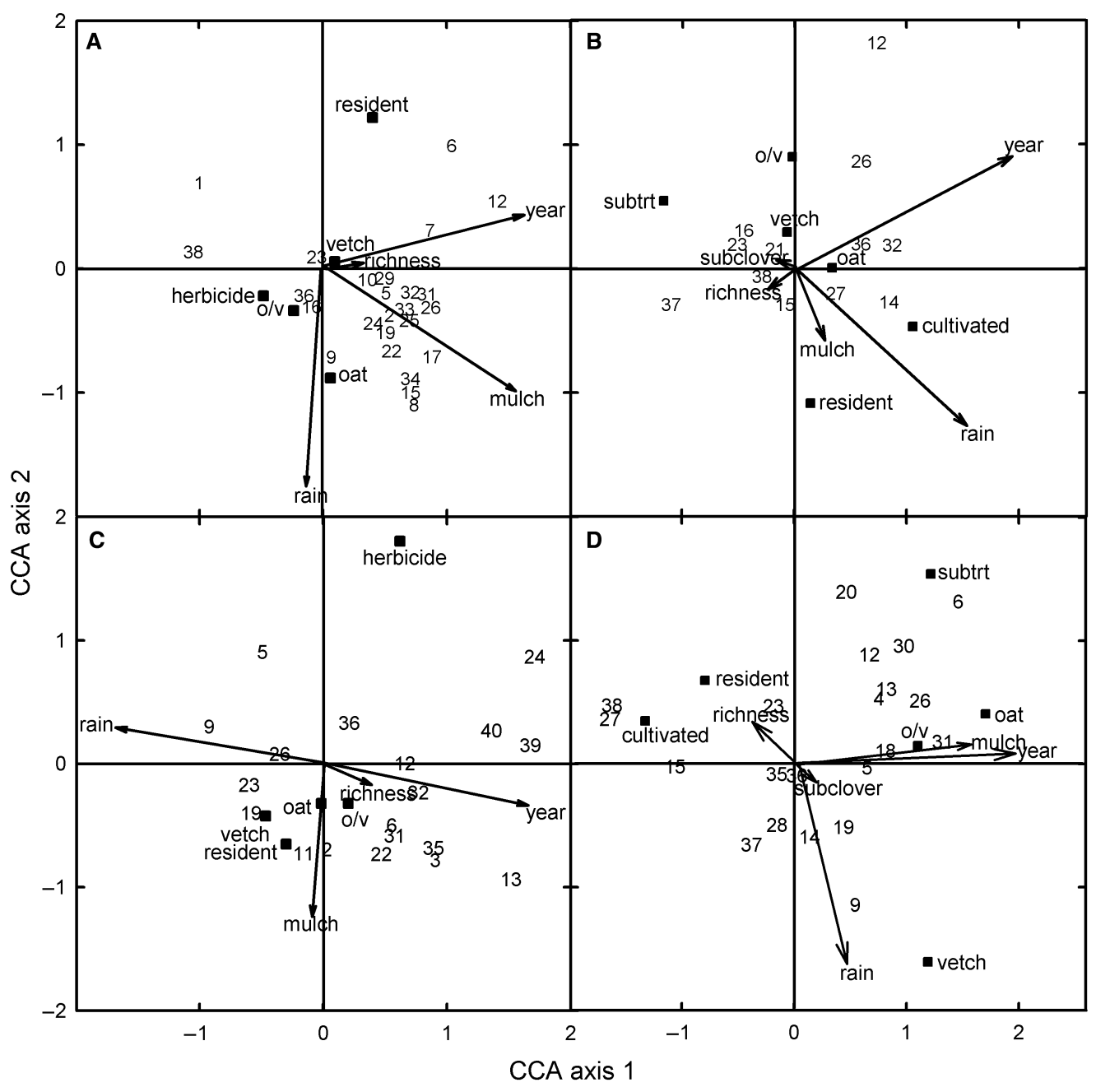

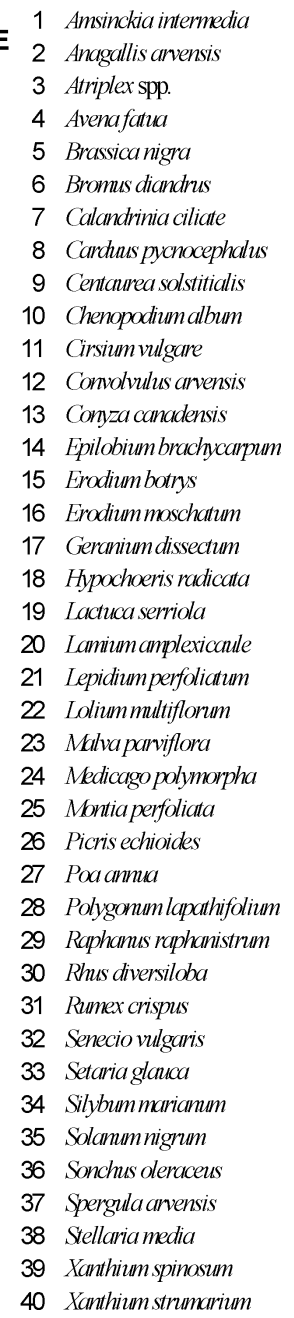

Fig. 2 Canonical correspondence analysis biplots at (A) Carneros in March, (B) Dry Creek in March, (C) Carneros in August and (D) Dry Creek in August. (E) Species numbers used in (A)-(D). Quantitative environmental variables (arrows) are mulch cover (mulch), time (year), species richness (richness), cumulative precipitation (rain) up to each assessment date for each year. Nominal environmental variables (ם) are the main treatments (oat, vetch, o/v, resident, herbicide).

obtain $75 \%$ weed cover suppression at Carneros and Dry Creek in 1994, respectively, which is much lower than the 97\% cover predicted in Teasdale et al. (1991). Perhaps, this was due to the heavier mulch production at Carneros and the lack of weed pressure at Dry Creek during that dry year. Effective weed suppression and lack of soil disturbance in previous years, attributable to high mulch application rates at Carneros and a persistent mulch cover at Dry Creek, may also explain the lower mulch cover estimates. However, $63 \%$ and $74 \%$ mulch cover would be required at Carneros and Dry Creek, respectively, during the heavy precipitation year of 1993.

Annual legume residues may exude allelochemicals to suppress germination and growth of weed species (White et al., 1989; Liebman \& Davis, 2000). Allelopathy associated with the subterranean clover may explain the significant weed suppression that was observed throughout the experiment at Dry Creek, especially in
1994 when the subclover only attained $11 \%$ cover. However, this could also be attributed to the effective weed suppression from previous years, because of the persistent mulch and lack of soil disturbance. Mulch and subclover residue from previous years may have also prevented subclover seeds from contacting the soil and re-establishing in 1994.

Soil bulk density was higher at Dry Creek than at Carneros where the soil contained a higher fraction of clay and organic matter. Additionally, a dairy farm occupied the Carneros site prior to its conversion to vineyard 3 years before this study began. These differences may explain the higher productivity of weeds and oat cover crop and the higher mulch breakdown rate at Carneros. Soil characteristics and higher mulch biomass applied to the vine rows may also explain why subclover did not ever become established in the vine rows at Carneros. 


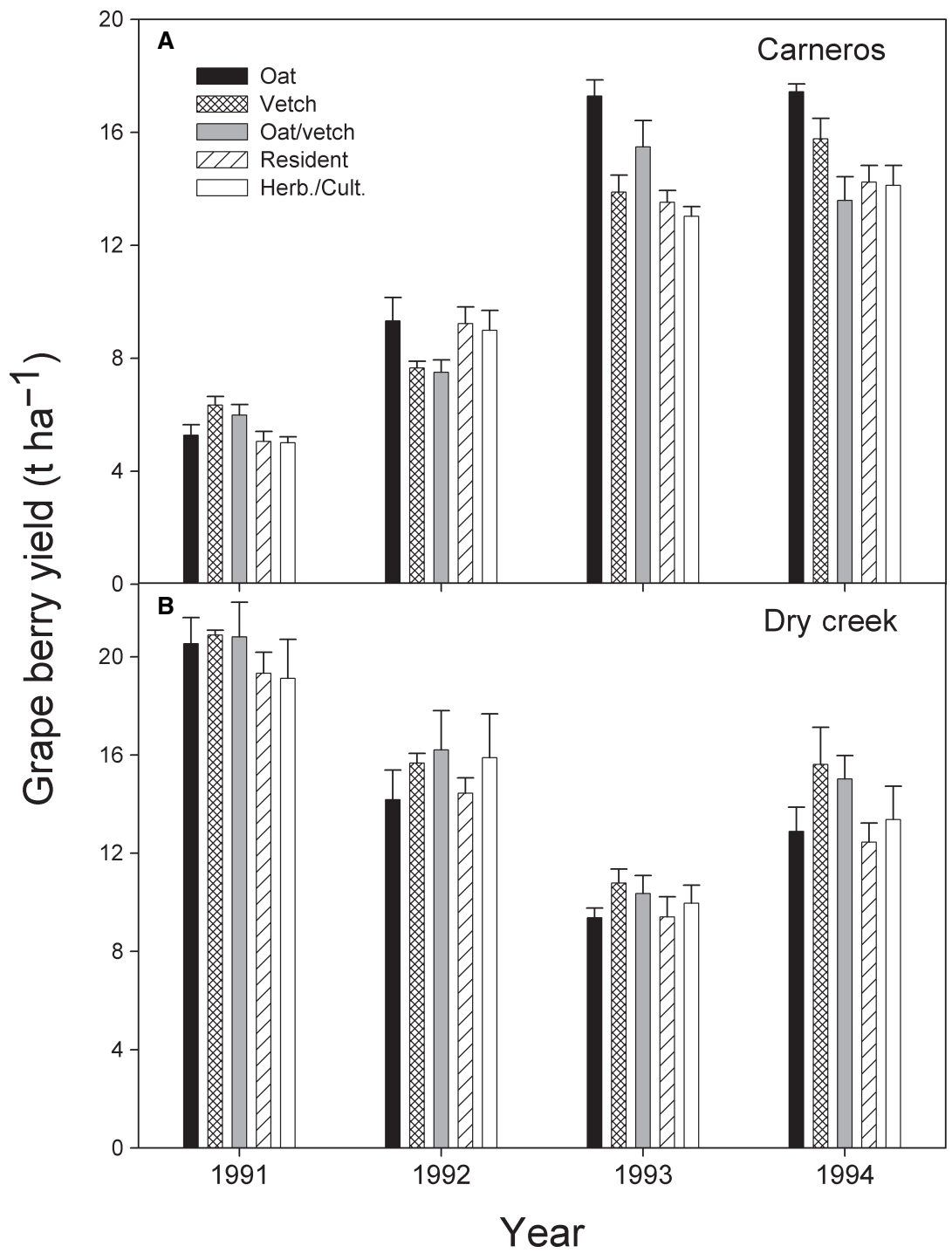

Fig. 3 Grape berry yield $\left(t \mathrm{ha}^{-1}\right)$ for 1991 through 1994 at (A) Carneros $(\mathrm{MSE}=2.15545$ d.f.) and (B) Dry Creek $(\mathrm{MSE}=3.613,45$ d.f.). Vertical bars represent standard errors of the mean.
We found C. arvensis to be adaptable to a variety of tillage and no-tillage management systems, as reported in Zaragoza et al. (1989). The increase of the perennial, $C$. arvensis, and the small seeded species, B. nigra, appeared to match the predictions made by Facelli and Pickett (1991) for mulched systems. At their best, the two conventional methods provided nearly $100 \%$ weed control just after they were applied or performed each year. However, weed suppression in the herbicide and cultivation treatments were among the worst by the end of the experiment in August 1994. The herbicide mixture used in this study effectively controls most annuals and will therefore tend to favour perennial species such as C. arvensis. This could also be seen in the significant reduction in species richness associated with this treatment.

Despite differences and changes in weed suppression, mulch production and weed flora among the treatments, there were no significant differences in overall grape yield within a given year. This research should provide a level of assurance that grape yields will not decrease by adopting a cover crop mulching system. Furthermore, the combination of slightly lower costs and consistently higher yields in the cover cropped systems resulted in $€ 794 \mathrm{ha}^{-1}$ higher average profits than those in the conventional systems.

This research demonstrated that weed suppression, grape yields and profits under a mulched cover crop system were similar to, and often exceeded, what was observed in conventional tillage and herbicide systems. However, the cover crop must be grown in an area larger than the area intended to receive the mulched cover crop. The cover cropping system appeared to be selfregulating by producing an appropriate mulch biomass for the likely weed pressure. The mechanism of significant weed suppression associated with the subclover subplots deserves further attention. There was some evidence of species compositional changes, primarily 
Table 4 Economic comparisons between cover crop systems relative to conventional herbicide/cultivation systems incorporating totals costs of production and revenues into net returns (profit, $€ \mathrm{ha}^{-1}$ ) for Carneros and Dry Creek with subclover sowed (+SC) and without (-SC) for the years 1991 through 1994

\begin{tabular}{|c|c|c|c|c|c|}
\hline \multirow[b]{2}{*}{ Location } & \multirow[b]{2}{*}{ Treatment } & \multicolumn{4}{|c|}{ Profit $^{*} €$ ha $^{-1}$} \\
\hline & & 1991 & 1992 & 1993 & 1994 \\
\hline \multirow[t]{5}{*}{ Carneros } & Herbicide & 0 & 0 & 0 & 0 \\
\hline & Oat & 233 & 357 & 4414 & 3437 \\
\hline & Vetch & 1317 & -1397 & 885 & 1698 \\
\hline & Oat/vetch & 956 & -1536 & 2524 & -547 \\
\hline & Resisdent & 9 & 312 & 577 & 183 \\
\hline \multirow[t]{8}{*}{ Dry Creek } & Cultivated & 0 & 0 & 0 & 0 \\
\hline & Oat $(+\mathrm{SC})$ & 178 & -2083 & -1728 & -139 \\
\hline & Oat(-SC) & 2615 & -1529 & 432 & -942 \\
\hline & Vetch $(+\mathrm{SC})$ & 1157 & 78 & 314 & 852 \\
\hline & Vetch $(-S C)$ & 2056 & 455 & 390 & 2439 \\
\hline & Oat/vetch(+SC) & 1411 & 183 & 441 & 2397 \\
\hline & Oat/vetch(-SC) & 2050 & -773 & 1090 & 2083 \\
\hline & Resident & 230 & -1467 & -556 & -934 \\
\hline
\end{tabular}

*Assumed grape purchase price of $€ 1.04 \mathrm{~kg}^{-1}$.

involving the increase of a perennial and reduction of annuals. For this reason, various methods of weed suppression should be used in combination to prevent a weed flora that is tolerant of any single method used repeatedly.

\section{Acknowledgements}

The research was funded by the University of California Integrated Pest Management Competitive Research Grants Program (91FE027).

The authors thank Mary Hall and Anne MollerRacke formerly of Buena Vista Vineyards and Jeff Lyon of Gallo Family Vineyards for their co-operation on this project. The authors also thank Trimax Mowing Systems, Ltd. for use of the flail mower. Technical assistance from California Polytechnic State University students, Sean Berajas and Kerry Cooper is gratefully acknowledged.

\section{References}

BERRY DA (1987) Logarithmic transformations in ANOvA. Biometrics 43, 439-456.

Bond W \& GRundy AC (2001) Non-chemical weed management in organic farming systems. Weed Research 41, 383405.
Cross T \& Perry GM (1995) Depreciation patterns for agricultural machinery. American Journal of Agricultural Economics 77, 194-204.

Dastgheib F \& Frampton C (2000) Weed management practices in apple orchards and vineyards in the south island of New Zealand. New Zealand Journal of Crop and Horticultural Science 28, 53-58.

Facelli JM \& Pickett STA (1991) Plant litter: its dynamics and effects on plant community structure. Botanical Review 57, 1-32.

FAgeria NK, BALIGAR VC \& BAILey BA (2005) Role of cover crops in improving soil and row crop productivity. Communication in Soil Science and Plant Analysis 36, 2733-2757.

Hartwig NL \& Ammon HU (2002) Cover crops and living mulches. Weed Science 50, 688-699.

Hembree KJ \& Lanini WT (2006) Weeds. UC IPM Pest Management Guidelines: Grape. University of California Agriculture and Natural Resources no. 3448, pp. 90-108.

Krebs CJ (1999) Ecological Methodology, 2nd edn. BenjaminCummings, Menlo Park, CA, USA.

LePs J \& S Milauer P (2003) Multivariate Analysis of Ecological Data using CANOCO. Cambridge University Press, NY, USA.

Liebman M \& Davis AS (2000) Integration of soil, crop, and weed management in low-external-input farming systems. Weed Research 40, 27-47.

TEASDALE JR (1993) Interaction of light, soil moisture, and temperature with weed suppression by hairy vetch residue. Weed Science 41, 46-51.

TEAsDale JR \& Mohler CL (1993) Light transmittance, soil temperature, and soil moisture under residue of hairy vetch and rye. Agronomy Journal 85, 673-680.

Teasdale JR, Beste CE \& Potts WE (1991) Response of weeds to tillage and cover crop residue. Weed Science 39, 195-199.

UC IPM OnLine. Statewide Integrated Pest Management Program. University of California Agriculture and Natural Resources (http://www.ipm.ucdavis.edu/).

White RH, Worsham AD \& Blum U (1989) Allelopathic potential of legume debris and aqueous extracts. Weed Science 37, 674-679.

SAS FOR Windows Version 9.1 (2002-2003) SAs Institute, Cary, NC, USA

Wrucke MA \& ARnold E (1985) Weed species distribution as influenced by tillage and herbicides. Weed Science 33, 853856.

Zaragoza C, Sopena JM, Ochoa MJ, Aibar J \& GomezApARISI J (1989) Weed flora evolution in vineyards under different soil management systems. Proceedings 4th EWRS Symposium on Weed Problems in Mediterranean climates 1, 251-262. 